\title{
О ФАКТОРАХ, ОПРЕДЕЛЯЮЩИХ ИНДИВИДУАЛЬНЫЕ РЕАКЦИИ ЖИТЕЛЕЙ МЕГАПОЛИСА НА РЕЖИМ САМОИЗОЛЯЦИИ
}

\section{FEATURES OF THE INQUIRY FOR PSYCHOLOGICAL HELP IN THE EMERGENT SITUATION OF THE COVID-19 PANDEMIC \\ N. Tsvetkova \\ S. Pokrovskaya}

Summary: The article considers the main three types of stress caused by the emergent situation of the new COVID-19 virus pandemic. This is the stress of excessive fear for health, financial stability, and relationships with loved ones. As well as the stresses of a value crisis and long-term uncertainty. The reasons for differences in individual responses to these stresses are described. The most popular areas of psychological assistance to stabilize the emotional state are indicated.

Keywords: consultative psychological assistance, stress and value crisis, the hut-the exact fears.
Цветкова Наталья Афанасьевна

К.псх.н., дочент, Московский педагогический государственный университет, г. Москва

mynatulechka@mail.ru

Покровская Светлана Викторовна

К.nсх.н., дочент, Московский городской психолого-педагогический университет, г. Москва

Аннотация: В статье рассмотрены основные три типа стрессов, вызванных эмерджентной ситуацией пандемии нового вируса COVID-19. Это стресс избыточного страха за здоровье, финансовую стабильность и отношения с близкими. А также стрессы ценностного кризиса и долговременной неопределенности. Описаны причины различия индивидуальных реакций на указанные стрессы. Указаны наиболее востребованные направления оказания психологической помощи с целью стабилизации эмоционального состояния.

Ключевые слова: консультативная психологическая помощь, стресс, ценностный кризис, избыточные страхи.

Эти стрессы в той или иной мере испытали на себе все. Боялись даже те, кто говорил, что не боится. Самые отчаянные ковидные диссидентьы, отрицатели ковидных угроз, не могли не реагировать на общий климат в социуме. Как известно, жить в обществе и быть свободным от него невозможно.

Но индивидуальные реакции были разные. Почему? С нашей точки зрения, различия в индивидуальных реакциях на стрессы ковидной опасности обуславливают три фактора:

1. фактор психофизиологический (уровень свойственной человеку психологической адаптивности, наличие врожденной способности нервной системы «держать удар», не впадать в панику, не терять способность мыслить рационально и конструктивно);

2. фактор психологический (привычные копингстратегии, адекватность и устойчивость самооценки, навыки эмоциональной саморегуляции),

3. фактор сочиальный (наличие поддержки на уровне микросоциума - семьи и макросоциума коллег по работе или бизнесу и представителей других значимых для индивидуума социальных групп).

Запрос на преодоление избыточных страхов за свое здоровье в период март-июль текущего года был наиболее выражен в консультативной практике. Избыточными принято называть страхи, превышающие по своей вы- 
раженности те адекватные страхи, которые необходимы человеку в его повседневной жизни для обеспечения своей безопасности. Без адекватных страхов человечество просто не выжило в процессе своего эволюционного развития: они позволяют быстро и адекватно среагировать на опасность. Тогда как избыточные страхи мешают сориентироваться в ситуации, отвлекают восприятие ситуации от реальности, уводя в область фантазий. Их главная особенность - рождение неуверенности в будущем: а) в будущем вообще (иррациональная уверенность по типу «Так хорошо, как раньше, у меня в жизни уже не будет!»; б) в себе самом (иррациональные убеждения по типу «Мне еще никогда так трудно не было; во времена предыдущих кризисов я был моложе; я был более мотивирован; у меня были связи другого, более высокого уровня»); в) в окружающих, поскольку многие значимые люди из микро- и макро- социума не проявили достаточно лояльности и поддержки.

Некоторые люди с особенно лабильной подвижной психикой испытали в период самоизоляции появление фобий - страхов, которые никак не соотносятся с реальной угрозой, сосредотачивая человека на одной теме или ситуации, и даже панических атак.

Надо отметить, что после выхода из режима самоизоляции резко уменьшилось количество проявлений фобических страхов и панических атак. Побеждают здравые реакции адекватного страха, особенно в отношении страха за здоровье. Но вот в отношении работы или развития бизнеса (многие бизнесы получили в период самоизоляции тяжкие травмы и продолжают их получать) страхи зачастую остаются на уровне избыточных.

Стресс ценностного и когнитивного диссонанса во время периода самоизоляции был частично обусловлен тем, с какой амбивалентностью нашему обществу подавалась информация о режиме самоизоляции. С одной стороны, государство через СМИ говорило о смертельных опасностях пандемии и категорически утверждало, что в этом кризисе жить нельзя и от него необходимо самоизолироваться. Но в то же время, с другой стороны, людям рассказывали о том, что вот наступили «каникулы», можно сидеть дома и расслабляться. То есть люди получали две взаимоисключающие команды: «Опасно, замрите в самоизоляции!» А, с другой стороны: «Не волнуйтесь и расслабитесь!» Было похоже, что государственные СМ предполагали наличие в каждом человеке двух разных личностей, утративших связи между собой. В ответ у потребителей такого двойного сигнала возникал когнитивный и ценностный диссонансы.

В результате по окончанию самоизоляции появилось много людей, пересмотревших свои системы жизненных ценностей. Можно выделить две группы. Первая группа: это люди, которые осознали, что жизнь - это «миг между прошлым и будущим», и в нем надо больше заниматься собой; они не хотят оставаться трудоголиками и их запрос к психологу: «Как перестроить свою трудовую активность в сторону большей свободы для спорта, путешествий, отношений, секса, развлечений». Вторая группа: это люди, которые утвердились в мысли «будут деньги - мы все купим, здоровье в первую очередь»; они возвели в ранг главной незаменимой ценности деньги. Их запрос к консультанту «как перестроить свою трудовую активность в сторону большей доходности?» Вектор, указывающий направление консультативной помощи в этих случаях - побудить клиента оставаться честным с самим собой и не присваивать ценности окружающих.

Третий из упоминавшихся выше стрессов - это стресс неопределенности. Он был вызван отсутствием информации о длительности периода самоизоляции, о сроках окончания лок-дауна, когда закрыто перемещение через границы, приостановлена деятельность заведений общепита, закрыты для посетителей музеи, театры, выставки и парки. Особенность индивидуальной реакции по отношению к рискам, по отношению к неопределенности определялось характеристиками индивидуального психотипа. Их условно можно назвать «инноватор», «стабилизатор» и «консерватор».

По нашим наблюдениям, инноваторы составляют самую малочисленную группу. Это люди, которые всегда пытаются найти новое, умеют жить в ситуации неопределенности и непредсказуемости, предлагают непривычные решения, не боятся рисковать и дают себе право на ошибку. Более того, комфортно они чувствуют себя только в движении. Они как будто едут по жизни на двухколесном велосипеде: стоит им остановиться, и они упадут. Инноваторы в ситуации самоизоляции наслаждались тем, как быстро они перевели свои офисы на работу в удаленном режиме, какие схемы придумали на будущее. Те инноваторы, чей бизнес принципиально не переводился в он-лайн формат, успели за период самоизоляции придумать для себя новые бизнес идеи и воплотить их в жизнь.

Значительно более многочисленные группы составляют «консерваторы» и «стабилизаторы». Метафорически выражаясь, «консерваторы» едут по жизни на «трехколесном велосипеде», на котором очень удобно стоять на месте. Ключевая особенность их реакции на неопределенность - страх войти в новую дверь. Этот стресс действует на них губительно: они не хотят и очень боятся любых перемен. А «стабилизаторы» - это люди, у которых ярко выражена потребность все контролировать. В самоизоляцию они были озабочены, в основном, тем, что работа их сотрудников (учеников, студентов и т.д.) «на удаленке» уменьшает возможность контроля. А потому были сосредоточены, больше, чем раньше, на выстраивании новых систем контроля и новых мер наказания. 
Анализ консультативных историй позволил сделать вывод, что большинство людей не использовали такой важный инструмент управления негативными эмоциями, как физическая нагрузка, несмотря на обилие советов в СМИ и в соцсетях заняться гимнастикой ци-гун, йогой, танцами - всем тем, что дает физическую активность, позволяющую эвакуировать стресс из тела.

Оставались мало использованы горизонтальные связи - семейные, личные, профессиональные. Поддержка близких не использовалась в полную силу. Это происходит, вероятно, потому, что во многих современных семьях отсутствует атмосфера взаимопонимания и поддержки друг друга [5]. Создать ее в ситуации самоизоляции многие супруги не сумели.

Остается неосознанным и такой инструмент перестройки реакции на кризис, как поиск и освоение новых форм поведения. «Залипание» на старых способах поведения опасно именно отсутствием ресурсности. Обстоятельства изменились - значит, появилась возможность освоить новые способы поведения. Однако, большинство людей (из обратившихся за консультативной помощью) этой возможностью не воспользовалась.

Анализ показал и дефицит развитых навыков саморегуляции. Монотонность ежедневных действий, отсутствие творческих идей - вот что подлежит осознанию и коррекции.

Задача психолога - помочь клиентам развивать разнообразие и двигаться вперед необщими неизбитыми путями. Развивать креативность. Научиться генерировать новое, создавать свои варианты развития. С точки зрения личностного развития наступил удачный момент для того, чтобы выйти на следующий уровень.

\section{ЛИТЕРАТУРА}

1. Цветкова Н.А. Консультирование семьи в трудных жизненных ситуациях. - Развитие личности, 2016. - №2, С. 157 - 178.

2. Зырянова Е.В., Цветкова Н.А. Консультативная работа с семьями в ситуации развода методом визуализации социально-психологических сетей. - Развитие личности, 2013 - № 4, С. 160 - 170.

3. Зырянова Е.В., Цветкова Н.А. Семья в ожидании ребенка: латентно-критический период // Теория и практика общественного развития// 2014. № 19. C. 238-240.

4. Бернштейн Н.А. Биомеханика и физиология движений. Избранные психологические труды. 3-е изд., стер. Бернштейн Н. А. (сборник) - Серия: Психологи России - Издательство: МПСИ, 2008.

5. Ц Цветкова Н.А. Трансформация семейных ролей как ведущая тенденция современного этапа развития института семьи. - Школа будущего. - 2018. - №4. - C. 41-46. 